\title{
Design of an Active Edible Coating Based on Sodium Caseinate, Chitosan and Oregano Essential Oil Reinforced with Silica Particles and Its Application on Panela Cheese
}

\author{
Luis Fernando Ríos-de-Benito ${ }^{1}$, Monserrat Escamilla-García ${ }^{1}$, Blanca García-Almendárez ${ }^{1}$, Aldo Amaro-Reyes ${ }^{1}$, \\ Prospero Di Pierro ${ }^{2,3}$ (I) and Carlos Regalado-González ${ }^{1, *}$ \\ 1 Facultad de Química, Departamento de Investigación y Posgrado en Alimentos, \\ Universidad Autónoma de Querétaro, Querétaro 76010, Mexico; lrios30@alumnos.uaq.mx (L.F.R.-d.-B.); \\ monserrat.escamilla@uaq.mx (M.E.-G.); blancag@uaq.mx (B.G.-A.); aldo.amaro@uaq.edu.mx (A.A.-R.) \\ 2 Centre for Food Innovation and Development in the Food Industry, University of Naples Federico II, \\ Via Università 133, 80055 Portici, Italy; prospero.dipierro@unina.it \\ 3 Department of Agricultural Sciences, University of Naples Federico II, Via Università 133, 80055 Portici, Italy \\ * Correspondence: carlosr@uaq.edu.mx; Tel.: +52-442-1238332
}

Citation: Ríos-de-Benito, L.F.; Escamilla-García, M.; GarcíaAlmendárez, B.; Amaro-Reyes, A.; Di Pierro, P.; Regalado-González, C. Design of an Active Edible Coating Based on Sodium Caseinate, Chitosan and Oregano Essential Oil Reinforced with Silica Particles and Its Application on Panela Cheese. Coatings 2021, 11, 1212. https:// doi.org/10.3390/coatings11101212

Academic Editor: Jaejoon Han

Received: 2 September 2021

Accepted: 29 September 2021

Published: 2 October 2021

Publisher's Note: MDPI stays neutral with regard to jurisdictional claims in published maps and institutional affiliations.

Copyright: (c) 2021 by the authors. Licensee MDPI, Basel, Switzerland. This article is an open access article distributed under the terms and conditions of the Creative Commons Attribution (CC BY) license (https:// creativecommons.org/licenses/by/ $4.0 /)$.

\begin{abstract}
Active edible films and coatings incorporating antimicrobial agents such as essential oils are studied to improve the shelf-life of fresh foods. The aim of this work was to study a mixture of sodium caseinate-chitosan (SC:CH), added with mesoporous silica nanoparticles filled with oregano essential oil (MSN-OEO), to produce an active edible coating for Panela cheese and to evaluate its properties during refrigerated storage for 15 days. The OEO was extracted by hydrodistillation and was incorporated into the MSN. Films based on SC:CH of 4:1 and 8:1 ratios with and without MSNOEO were produced and the mechanical, barrier, physicochemical and microbiological properties of the films were evaluated. The SC:CH 8:1 ratio $(w / w)$ with MSN-OEO showed reduced mean particle size $(764.8 \pm 23.3 \mathrm{~nm})$, and a stable solution (zeta potential $=29.9 \pm 1.1 \mathrm{mV}$ ). The thickness and solubility were influenced by the incorporation of MSN-OEO making it thinner and less soluble. Panela cheese samples were coated by the spray method using the SC:CH 8:1 containing MSN-OEO film forming solution. The final $\mathrm{pH}$ of the control cheese was 0.5 units lower than that of the coated cheese, whereas final moisture loss of the control cheese was 4.2 times that of the coated cheese. The mesophilic aerobic bacteria and of molds and yeasts populations achieved a reduction of about $2 \log _{10} \mathrm{UFC} / \mathrm{g}$ after 15 days of storage. Due to microbial growth delay, and little moisture loss, this active coating may improve the quality and safety of Panela cheese.
\end{abstract}

Keywords: edible coating; sodium caseinate; chitosan; oregano essential oil; Panela cheese

\section{Introduction}

In the last few years, advances in the production of edible coatings and films using different compounds from renewable sources has been provided. In fact, it is well known that barrier, mechanical and optical properties of films and coatings depend on both the chemical-physical properties of utilized compounds and their specific interactions $[1,2]$. Chitosan, derived from chitin deacetylation is one of the most widely studied and used biopolymers for the preparation of edible films and coatings due to its excellent film forming ability, biodegradability and antimicrobial properties [3]. Sodium caseinate is soluble casein obtained through the acidic precipitation of milk with subsequent solubilization in sodium hydroxide [4]. Sodium caseinate shows good film-forming and thermoplastic properties due to its random coil structure, and its ability to form weak intermolecular interactions [5,6]. However, it does not confer antimicrobial properties.

Panela cheese is a type of fresh cheese made from pasteurized cow's milk very popular in Mexico, where its production accounted for 418,560 tons in 2018 [7]. In addition, it is 
the most popular Hispanic-style cheese consumed in the USA [8]. It is white, with a porous, soft and fluffy texture with low fat content. The shelf life of fresh cheeses is about 15-18 days, due to its high moisture content and nutrients availability [9].

Cheese packaging is practiced to minimize weight loss due to moisture loss, and to prevent microbial contamination and spoilage without affecting the cheese composition $[10,11]$. Edible coatings are applied directly to the surface of the food, where a thin layer forms after drying, while the films dry separately to form a material that is then used to cover the food.

Essential oils (EOs) are concentrated oily liquids obtained from plant materials such as flowers, buds, leaves and bark, which contain a mixture of volatile aromatic compounds including terpenes, terpenoids (oxygenated terpenes) and phenols [12,13]. EOs have shown antimicrobial properties against foodborne pathogens, i.e., bacteria, molds and their associated toxins [14]. The antimicrobial activity of essential oils may be regulated by more than one mechanism of action, including changes in the fatty acid profile of the cell membrane, damage of the cytoplasmic membrane and disruption of the protonmotive force $[13,15]$. However, due to the high volatility and diffusivity of essential oils in foods, the development of strategies able to increase their retention and release control, are the main challenges that need to be solved. EOs encapsulation is a promising technique that offers numerous advantages, such as ease of handling, stability, protection against oxidation, improved distribution, solubility, controlled release, with little or no effect on the organoleptic properties of foods to which they are applied with improved bioavailability $[1,16]$.

Mesoporous silica nanoparticles (MSNs) are a good system for encapsulating essential oils due to their porous structure, chemical stability, biocompatibility, adjustable pore size and porosity, simple and low-cost synthesis, and possible expansion for industrial use. Furthermore, silica is biologically inert, and can break down into relatively harmless silicic acid by-products $[17,18]$.

The aim of this study was to evaluate the physicochemical, mechanical and barrier properties of sodium caseinate and chitosan films, added with mesoporous silica particles filled with oregano essential oil (OEO). In addition, this formulation was tested as coating of fresh Panela cheese and the microbiological and physicochemical changes were evaluated throughout 15-days storage period.

\section{Materials and Methods}

\subsection{Materials}

Sodium caseinate was purchased from Fonterra Group (Auckland, the Netherland), Chitosan Powder (90\% deacetylation; viscosity 50-800 mPa.s) was obtained from Chemsavers (Bluefield, VA, USA). Anhydrous glycerol was purchased from J.T. Baker (Radnor, PA, USA); lactic acid (85\%), cetyltrimethylammonium bromide (CTAB) and tetraethyl orthosilicate (98\%) (TeOS) were purchased from Sigma-Aldrich (St. Louis, MO, USA). Fresh oregano leaves (Lippia graveolens Kunth) were collected in Cerrito Parado, Tolimán (Querétaro, México). A voucher specimen was authenticated and deposited in the Ethnobotanical Collection of the Herbarium of Querétaro "Dr. Jerzy Rzedowski" (QMEX), located at the Faculty of Natural Sciences, University of Querétaro, Mexico (voucher specimen: E. Hernández-Hernández No. 1). Potato dextrose agar, plate count agar and casein peptone were acquired from BD Bioxon (Estado de Mexico, México).

All bacteria tested were obtained from the microbial collection of the Food Biotechnology Laboratory, DIPA, Universidad Autónoma de Querétaro (Mexico). Selected bacteria were those relevant in microbial contamination of fresh cheese, Listeria innocua and Salmonella Saintpaul. The strains were stored at $-60^{\circ} \mathrm{C}$ in sterile glycerol. The bacteria were activated in nutrient broth (Bioxon) at $37^{\circ} \mathrm{C}$ for $24 \mathrm{~h}$. 


\subsection{Extraction of Oregano Essential Oil (OEO)}

The oregano leaves were air-dried at room temperature for 3 days in a dark chamber. The dry material was stored in black polyethylene bags until use [19]. Dry oregano leaves (700 g) were suspended in $5 \mathrm{~L}$ of distilled water and subjected to hydrodistillation for $2 \mathrm{~h}$, using a Clevenger-type apparatus (Cristalab, CDMX, México). The obtained OEO was dried with anhydrous sodium sulfate, sterilized by filtration using a Swinnex unit of $0.45 \mu \mathrm{m}$ pore size polyvinylidene fluoride (PVDF) membrane (Millipore, Burlington, MA, USA), and then stored in sealed vials protected from light at $4{ }^{\circ} \mathrm{C}$ for later use [20].

\subsection{MSN-OEO Preparation}

The MSN were synthesized, as previously reported [21], with modifications. In a solution of $240 \mathrm{~mL}$ of distilled water and $1.75 \mathrm{~mL}$ of $2 \mathrm{~N} \mathrm{NaOH}, 0.5 \mathrm{~g}$ of CTAB was dispersed by using an ultrasonic bath at room temperature. The sample was heated up to $80^{\circ} \mathrm{C}$ under constant stirring and then $2.5 \mathrm{~mL}$ of TeOS was added drop by drop during $5 \mathrm{~min}$, and vigorously stirred for $2 \mathrm{~h}$ at $80^{\circ} \mathrm{C}$. The solid product was obtained by filtration, then washed with ethanol, and finally calcined at $500{ }^{\circ} \mathrm{C}$ for $5 \mathrm{~h}$ to remove the surfactant. The obtained MSNs $(0.1 \mathrm{~g})$ were dispersed into $2 \mathrm{~mL}$ of ethanol containing $0.1 \mathrm{~g}$ of the OEO. The final mixture was stirred overnight in a fume cupboard at room temperature to remove the ethanol.

The amount of OEO in the MSN-OEO particles was determined by suspending $5.0 \mathrm{mg}$ of the samples in $10 \mathrm{~mL}$ of ethyl acetate, followed by centrifugation (IKA, Wilmington, NC, USA) at $10,000 \times g$ for $10 \mathrm{~min}$. The supernatant containing the released OEO was quantified from a calibration curve constructed with different OEO concentrations in ethyl acetate, and measuring absorbance at $270 \mathrm{~nm}$ using a spectrophotometer (UV-1800 Shimadzu, Kioto, Japan) [22]. The released OEO was subtracted from the total OEO to obtain the amount of OEO in the MSN.

\subsection{Preparation of SC:CH Film Forming Solution (FFS)}

The SC solution was prepared at $0.90 \%(w / v)$ in distilled water and stirred at $40{ }^{\circ} \mathrm{C}$ for $30 \mathrm{~min}$, then the $\mathrm{pH}$ was adjusted to 5.3 . The solution of chitosan $1 \%(w / v)$ in lactic acid $(1 \% v / v)$ was stirred for $60 \mathrm{~min}$ at $80^{\circ} \mathrm{C}$, once dissolved, the $\mathrm{pH}$ was adjusted to 5.8; each solution was kept under stirring until complete dissolution. To produce the FFS, SC $(360 \mathrm{mg}$ ) was added to the $\mathrm{CH}$ at 4:1 and 8:1 (SC: $\mathrm{CH} w / w)$ ratios, under stirring at $700 \mathrm{rpm}$. The MSN-OEO was suspended in distilled water $(20 \mathrm{mg} / \mathrm{mL})$ at $\mathrm{pH}=10$ and added to the FFS ( $3 \%$ relative to the total mass of SC plus $\mathrm{CH}, w / w)$. Glycerol was added as plasticizer at $30 \%$ of $\mathrm{SC}(w / w)$, and the mixture was adjusted to $\mathrm{pH} 5.3$, followed by gently stirring for $20 \mathrm{~min}$. Finally, the FFS was homogenized using an Ultra-Turrax (IKA T25, Staufen, Germany) at $9500 \mathrm{rpm}$ for $2 \mathrm{~min}$.

\subsection{Characterization of the FFSs and Films}

\subsection{1. $\zeta$-Potential and Particle Size Measurement}

One $\mathrm{ml}$ of each FFS was analyzed for $\zeta$-potential and particle size by using a Zetasizer

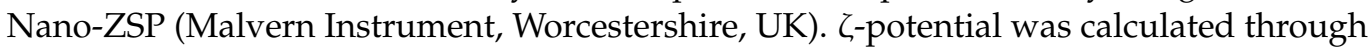
the electrophoretic mobility by applying a voltage of $200 \mathrm{mV}$ and using the HelmholtzSmoluchowski equation. Hydrodynamic size was obtained from dynamic ligh scattering by using a He-Ne laser (wavelength of $633 \mathrm{~nm}$ ) and a detector angle of $173^{\circ}$.

\subsubsection{Film Preparation}

Films were prepared by the casting method. Each FFS $(45 \mathrm{~mL})$ was poured into $8 \mathrm{~cm}$ diameter polyester Petri dishes and dried at $38{ }^{\circ} \mathrm{C}$ and $50 \%$ relative humidity (RH) in an environmental chamber (Binder, KBF 115, Tuttlingen, Germany), for $18 \mathrm{~h}$. Film thickness was measured with a digital micrometer (Mitutoyo, 293-185, Kawasaki, Japan) at five random points over the film, and the mean \pm standard deviation (SD) of five replicates was reported. 


\subsubsection{Mechanical Properties}

Film tensile strength (TS), elongation at break (EB) and Young's modulus (YM) were measured by using an Universal testing instrument (Instron Engineering, model No. 5543A, Norwood, MA, USA) as previously described [23]. Film samples were cut, using a sharp razor blade, into $10 \mathrm{~mm}$ wide and $40 \mathrm{~mm}$ length strips equilibrated overnight at $50 \% \pm 5 \%$ $\mathrm{RH}$ and $23 \pm 2{ }^{\circ} \mathrm{C}$ in an environmental chamber. Five samples of each film type were tested.

\subsubsection{Barrier Properties}

Film permeabilities to gas $\left(\mathrm{O}_{2}\right.$ and $\left.\mathrm{CO}_{2}\right)$ and water vapor $(\mathrm{WV})$ were determined by using a MultiPerm apparatus (Extrasolution s.r.l., Pisa, Italy). Duplicate samples of each film were conditioned for 2 days at $50 \%$ RH before measurement. Aluminum masks were used to reduce the film test area to $5 \mathrm{~cm}^{2}$, whereas the testing was performed at $25{ }^{\circ} \mathrm{C}$ under $50 \% \mathrm{RH}$.

\subsubsection{Solubility}

The solubility of films was determined according to Vahedikia et al. [24]. The initial dry matter of samples was determined by placing the films in a desiccator containing calcium sulfate at $25{ }^{\circ} \mathrm{C}$ and $0 \%$ relative humidity (RH) for $24 \mathrm{~h}$. The films were then immersed in $50 \mathrm{~mL}$ distilled water and then placed in a shaker incubator at $25{ }^{\circ} \mathrm{C}$ and stirred for $24 \mathrm{~h}$ at $250 \mathrm{rpm}$. The film solubility (\%) was calculated using Equation (1):

$$
\text { Solubility }(\%)=\frac{\text { Initial dry weight }- \text { Final dry weight }}{\text { Initial dry weight }} \times 100
$$

\subsubsection{Scanning Electron Microscopy (SEM)}

Microstructural analysis of cross-sections of the films was carried out by using SEM, in a JEOL JSM-5410 (Tokyo, Japan) electron microscope. Pieces of $5 \mathrm{~mm} \times 5 \mathrm{~mm}$ were cut from films and mounted on copper stubs. Films were fixed on the support using double side adhesive tape. Samples were gold coated and observed using an accelerating voltage of $10 \mathrm{kV}$.

\subsubsection{Color and Transparency}

The color of the films was evaluated according to the CIELAB method, using a Minolta CR400 colorimeter (Minolta, Osaka, Japan) with the parameters $\mathrm{L}^{*}=$ lightness, $\mathrm{a}^{*}=$ green to red color component and $\mathrm{b}^{*}=$ blue to yellow color component. The color was standardized using a white reference plate.

The transparency of films was determined according to Lin et al. [6], with modifications. The edible film was cut into strips $(1 \mathrm{~cm} \times 4 \mathrm{~cm})$, and the top and bottom edges of the specimen were fixed on the surface of a quartz cuvette with adhesive tape, and the transmittance at $600 \mathrm{~nm}$ was measured using a spectrophotometer. The transparency was calculated using Equation (2):

$$
\mathrm{T}=\frac{\mathrm{A}_{600}}{\delta}
$$

where: $\mathrm{T}=$ transparency; $\mathrm{A}=$ absorbance; $\delta=$ thickness.

\subsubsection{Atomic Force Microscopy (AFM)}

The surface roughness of the coating used on Panela cheese (SC:CH, 1:8 with and without SMN.OEO) was estimated by atomic force microscopy (AFM), according to EscamillaGarcía et al. [25], by means of an atomic force microscope (di Multimode V, Veeco, Plainview, NY, USA) in contact mode. Film pieces of $0.5 \mathrm{~cm} \times 0.5 \mathrm{~cm}$ were used, and the resonance frequency of scanning was $286-362 \mathrm{kHz}$ with a spring constant of $20-80 \mathrm{~N} / \mathrm{m}$, scanning speed of $1 \mathrm{~Hz}$ and resolution of $256 \times 256$ pixels. The results were analyzed using the Gwyddion Version 2.53 software (Okružní, Czech Republic). The roughness was obtained by evaluating the square root of the deviation from an average plane of the peaks and 
surface valleys (Rq) (Equation (3). The mean absolute value of surface height deviations from the middle plane ( $\mathrm{Ra})$, was estimated from Equation (4).

$$
\begin{aligned}
& \mathrm{R}_{\mathrm{q}}=\sqrt{\frac{\sum \mathrm{Z}_{\mathrm{i}}^{2}}{\mathrm{~N}}} \\
& \mathrm{R}_{\mathrm{a}}=\frac{1}{\mathrm{~N}} \sum_{\mathrm{j}=1}^{\mathrm{N}} \mathrm{Z}_{\mathrm{j}}
\end{aligned}
$$

where $\mathrm{Ra}$ and $\mathrm{Rq}$ indicate the roughness ( $\mathrm{nm}), \mathrm{Zi}$ and $\mathrm{Zj}$ are the height difference of $\mathrm{i}$ and $\mathrm{j}$ relative to the heights average, and $\mathrm{N}$ is the number of points on the image.

\subsubsection{Antimicrobial Activity}

Antimicrobial activity was evaluated following Hernández-Hernández et al. [20]. Briefly, $10 \mathrm{~mL}$ of trypticase soy agar $(0.8 \% w / v$ (Bioxon) was inoculated with $200 \mu \mathrm{L}$ of L. innocua solution ( $\left.10^{7} \mathrm{CFU} / \mathrm{mL}\right)$ or $100 \mu \mathrm{L}$ of S. Saintpaul $\left(10^{7} \mathrm{CFU} / \mathrm{mL}\right)$, subsequently poured onto plates containing solidified agar $(1.5 \% w / v)$.

Disks were prepared from films of SC:CH at 8:1 ratio $(w / w)$ with and without MSNOEO of $25 \mathrm{~mm}$ in diameter. Additionally, PVDF membrane disks of $25 \mathrm{~mm}$ in diameter (Darmstadt, Germany) were impregnated with $8 \mathrm{mg}$ of MSN-OEO or $75 \mu \mathrm{L}$ of OEO diluted at $25 \%(w / v)$ with Tween 80 at $10 \%(v / v)$. One disk of each was gently placed on top of the soft agar layer and OEO were allowed to diffuse for $2 \mathrm{~h}$, at $4{ }^{\circ} \mathrm{C}$ and then incubated at $37^{\circ} \mathrm{C}$ for $48 \mathrm{~h}$. The growth inhibition zone, which included the disk diameter, was measured using Vernier callipers.

\subsection{Application as a Coating on Panela Cheese}

The coating was applied on samples of Panela cheese using a spray gun (Husky, Lincoln, NE, USA) the samples were sprayed 2 times at 2 min interval. After the coating process, all samples were drained on stainless steel screens and air-dried in a laminar flow cabinet for $20 \mathrm{~min}$, and then were put into plastic "clam-shell" containers (Industry standard, 9756Z, Pactiv Corp., Zapopan, México) and stored at $4{ }^{\circ} \mathrm{C}$. The cheese was subjected to physicochemical and microbiological analyses at 0 day, 5 days, 10 days and 15 days of storage. Uncoated cheeses were used as control, and were stored and analyzed at the same times.

\subsubsection{Moisture Content, $\mathrm{pH}$ and Titratable Acidity}

The moisture content (MC) in Panela cheese was analyzed by moisture analyzer XM50 (Precisa Gravimetrics AG, Dietikon, Switzerland) by using $1 \mathrm{~g}$ of homogenized cheese, and moisture was expressed as weight \%. Titratable acidity and $\mathrm{pH}$ were evaluated following the Mexican standard NOM-243-SSA1 [26]. The $\mathrm{pH}$ was detected by using $1 \mathrm{~g}$ of cheese homogenized in $10 \mathrm{~mL}$ of distilled water, and from each sample, $3 \mathrm{pH}$ measurements were taken using a calibrated potentiometer Orion (Star A211, Thermo Scientific, Waltham, MA, EUA). Titratable acidity was evaluated using $18 \mathrm{~g}$ of homogenized cheese in $36 \mathrm{~mL}$ of distilled water, followed by titration with $0.1 \mathrm{~N} \mathrm{NaOH}$ until the appearance of a pink color for at least $30 \mathrm{~s}$. The results are expressed as\% lactic acid $(w / w)$.

\subsubsection{Microbiological Analysis}

Molds and yeast, and mesophilic aerobic bacteria were quantified according to the Mexican standard [26]. Panela cheese with and without coating at 0 day, 5 days, 10 days and 15 days of storage were analyzed in triplicate.

Molds and Yeasts

For the population of molds and yeasts the cheese was homogenized followed by serial decimal dilutions; then $1 \mathrm{~mL}$ of each dilution was poured into potato dextrose agar 
(Bioxon), previously adjusted to $\mathrm{pH}=3.5 \pm 0.1$ by using $10 \%$ tartaric acid (J.T. Baker), and incubated at $25 \pm 1{ }^{\circ} \mathrm{C}$. Colonies (CFU/g) were evaluated after 3 days of incubation, and results were reported as $\log _{10} \mathrm{CFU} / \mathrm{g}$.

\section{Mesophilic Aerobic Bacteria}

The population of mesophilic aerobic bacteria of the cheese samples was performed using plate count agar, pouring $1 \mathrm{~mL}$ of decimal dilutions and incubating for $48 \mathrm{~h}$ at $35^{\circ} \mathrm{C}$. Results were reported as $\log _{10} \mathrm{CFU} / \mathrm{g}$.

\subsection{Statistical Analysis}

Experiments were made in triplicate, and analysis of variance (ANOVA) was performed using the JMP software 13.0 (SAS Institute, Cary, NC, USA). Tukey's multiple range test was used, differences at $p<0.05$ were considered significant and are indicated with different letters.

\section{Results and Discussion}

\subsection{SEM of MSN and MSN-OEO}

The MSNs before the addition of OEO exhibited large aggregates with size about $360 \mathrm{~nm}$, possibly due to the interaction of microaggregates (Figure 1A). When OEO was added to the MSNs, a more homogeneous surface was observed indicating better particles dispersion, leading to a decreased particle size of about $250 \mathrm{~nm}$ (Figure 1B). This is probably associated to OEO encapsulation within the MSNs pores and over the particles surface counteracting their coalescence.

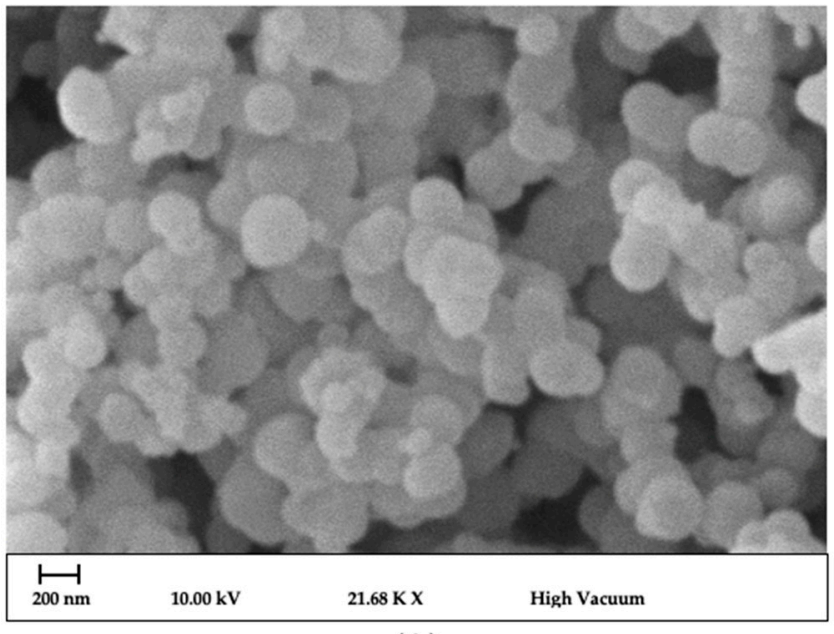

(A)

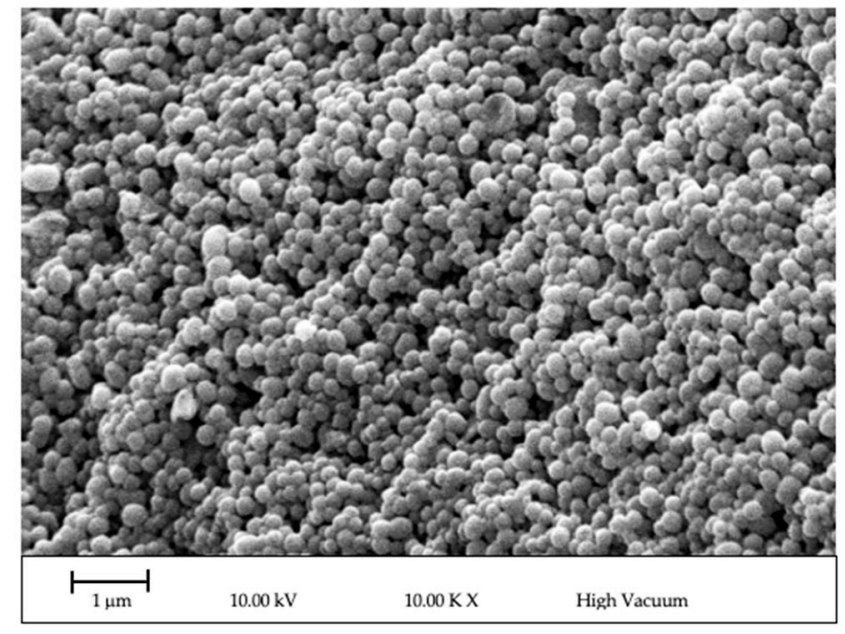

(B)

Figure 1. SEM micrographs of (A) MSN and (B) MSN-OEO. Magnification: $21,680 \times($ A) and 10,000 $\times($ B) .

\subsection{FFSs Stability}

It is well known that $\zeta$-potential can be correlated with the stability of dispersions that can be classified according to their absolute values as follows: 0-10 $\mathrm{mV}$ highly unstable, $10-20 \mathrm{mV}$ relatively stable, $20-30 \mathrm{mV}$ moderately stable and $>30 \mathrm{mV}$ as highly stable [27].

Preliminary experiments on the mixing of $\mathrm{SC}(\mathrm{pI}=4.5)$ and $\mathrm{CH}(\mathrm{pKa}=6.0)$ demonstrated that to produce stable complexes, the $\mathrm{pH}$ of the stock solutions must be $\mathrm{pH} 5.3$ for $\mathrm{SC}$ and $\mathrm{pH} 5.8$ for $\mathrm{CH}$, to counteract clotting and phase separation. These conditions are useful to keep the biopolymers weakly charged and with opposite charges to facilitate low electrostatic interactions aiming to stabilize the complexes formed, while avoiding phase separation. In fact, according to Anal et al. [28] the SC: $\mathrm{CH}$ complexes precipitated at $\mathrm{pH}$ range $4-4.5$, and $\mathrm{pH}>6$, whereas the polymers tended to dissociate between $\mathrm{pH}$ 3 and 3.8 due to similar charges. On the other hand, stable complexes were formed at 
pH 5-6, which was attributed to the interaction of positive charge density and linear structure of $\mathrm{CH}$, in addition to the negative charge of SC [29]. Therefore, after preliminary experiments, the mixtures were made at $\mathrm{pH} 5.3$ to produce stable complexes, in agreement with Volpe et al. [30]. By comparing the $\zeta$-potential of the SC: $\mathrm{CH}$ dispersions obtained at different ratios and at $\mathrm{pH} 5.3$, it is possible to observe a greater stability at $4: 1$ ratio $(34.77 \mathrm{mV})$ compared to $8: 1(29.33 \mathrm{mV})$ even if the hydrodynamic radius is greater using the 4:1 ratio than 8:1 (Table 1). It is known that proteins have both positive and negative charges on the surface that can interact with each other, generating protein aggregates with a hydrodynamic radius of $1800.16 \mathrm{~nm}$. At the higher chitosan concentration (4:1), the positive charge density and linear structure of the $\mathrm{CH}$ destabilizes the protein-protein interactions by generating protein-chitosan complexes. Furthermore, the excess of $\mathrm{CH}$ can produce different complexes through the residual negative charges on the proteins, producing aggregates of about $1010.64 \mathrm{~nm}$. This effect increases the residual positive charges of both $\mathrm{CH}$ and proteins increasing the $\zeta$-potential. Conversely, a lower $\mathrm{CH}$ Content (SC:CH 8:1) favors the formation of isolated protein-chitosan aggregates in which the $\mathrm{CH}$ envelops the proteins giving rise to smaller particles $(781.33 \mathrm{~nm})$. Furthermore, the negative surface charge of the protein aggregates partially counteracts the positive charge of the complexes leading to decreased average $\zeta$-potential. Further experiments are needed to verify this hypothesis.

Table 1. $\zeta$ Potential, particle size and polydispersity index of the SC:CH FFSs at different ratios containing or not MSN-OEO.

\begin{tabular}{cccccc}
\hline SC:CH Ratio & pH & MSN-OEO & Particle Size (nm) & Z Potential (mV) & Polydispersity Index \\
\hline $0: 1$ & 5.8 & - & $1238.27 \pm 25.9^{\mathrm{d}}$ & $31.07 \pm 0.8^{\mathrm{c}}$ & $0.72 \pm 0.1^{\mathrm{c}}$ \\
$1: 0$ & 5.3 & - & $1800.16 \pm 10.2^{\mathrm{e}}$ & $27.77 \pm 0.8^{\mathrm{d}}$ & $0.53 \pm 0.1^{\mathrm{a}}$ \\
$4: 1$ & 5.3 & - & $1010.64 \pm 8.1^{\mathrm{a}}$ & $34.77 \pm 1.2^{\mathrm{a}}$ & $0.54 \pm 0.0^{\mathrm{a}}$ \\
$4: 1$ & 5.3 & + & $1008.00 \pm 4.5^{\mathrm{a}}$ & $36.93 \pm 1.2^{\mathrm{a}}$ & $0.39 \pm 0.1^{\mathrm{b}}$ \\
$8: 1$ & 5.3 & - & $781.33 \pm 11.7^{\mathrm{b}}$ & $29.33 \pm 1.3^{\mathrm{b}}$ & $0.53 \pm 0.0^{\mathrm{a}}$ \\
$8: 1$ & 5.3 & + & $764.80 \pm 23.3^{\mathrm{c}}$ & $29.93 \pm 1.1^{\mathrm{b}}$ & $0.50 \pm 0.0^{\mathrm{a}}$ \\
\hline
\end{tabular}

Results are reported as the mean \pm standard deviation $(n=3)$. Equal letters indicate that there is no significant difference $(p<0.05)$.

The stability of the FFSs (4:1 or 8:1 ratios) is not affected by the addition of MSN-OEO after the biopolymer complexation; in fact, no significant differences on the $\zeta$-potential values were observed (Table 1). Fernandez-Bats et al. [21] reported that in film-forming solutions of bitter vetch protein, MSNs higher than 3\% by weight destabilize the FFSs.

Similar to the effect on the particle size reduction observed by Navarro et al. [31], during the addition of different oil encapsulating agents in the film-forming solutions, the MSN-OEO significantly reduced the hydrodynamic size of the 8:1 SC:CH complex. Moreover, the samples showing PDI values $<0.6$ indicate a Gaussian particle size distribution [32]. This result was attributed to decrease of the interfacial tension between the oil and the aqueous phases by the encapsulating agent, because it reduces the free energy required to deform and interrupt the drops, resulting in smaller particles.

\subsection{Characteristics of the SC:CH Films}

\subsubsection{Microstructural Properties of Films}

The final microstructure of the films resulted from the components interactions and the destabilizing phenomena taking place during the drying stage. The addition of MSN-OEO particles to films of 8:1 SC:CH ratio, resulted in different surface patterns (Figure 2). The film without MSN-OEO showed a smooth and homogeneous microstructure (Figure 2A), whereas the surface of films containing the MSN-OEO (Figure 2B) reveal a less continuous structure with the particles already embedded on the surface of the film. The cross section of the SC:CH 8:1 MSN-OEO film shows that the OEO was incorporated with partly uneven distribution in the polymers matrix, displaying some micro-sized cracks and holes (Figure 2C2). Magnification of the cross section revealed that the dispersion of the MSN- 
OEO phase was well distributed throughout the films, showing layers of the MSN-OEO phase (Figure 2C1). A similar behavior was reported by Fabra et al. [33], with SC films containing mixtures of oleic acid and beeswax. Here, addition of the hydrophobic material changed the films microstructure from homogeneous and smooth surface to one showing the lipid mass embedded in the matrix of the film.

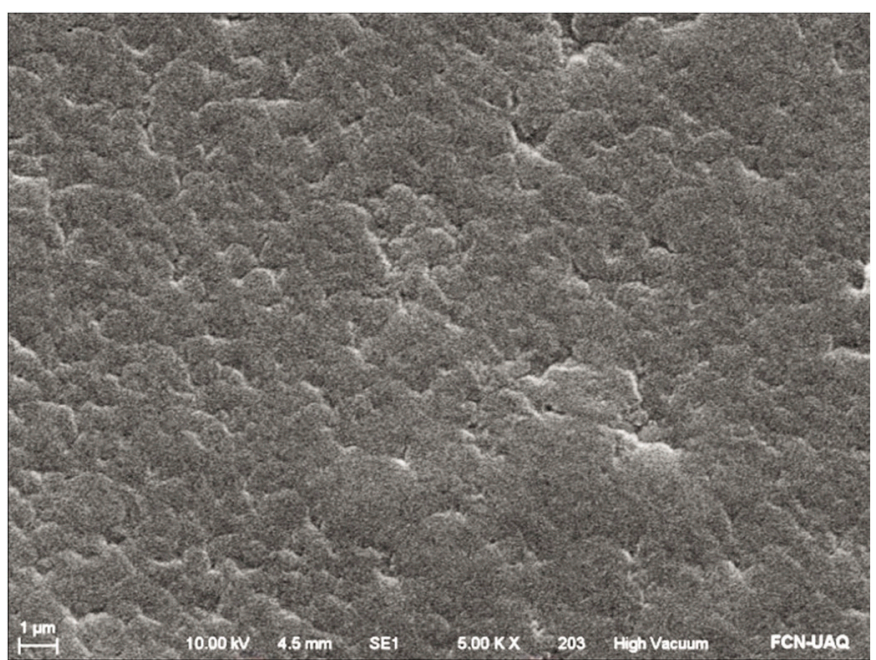

(A)

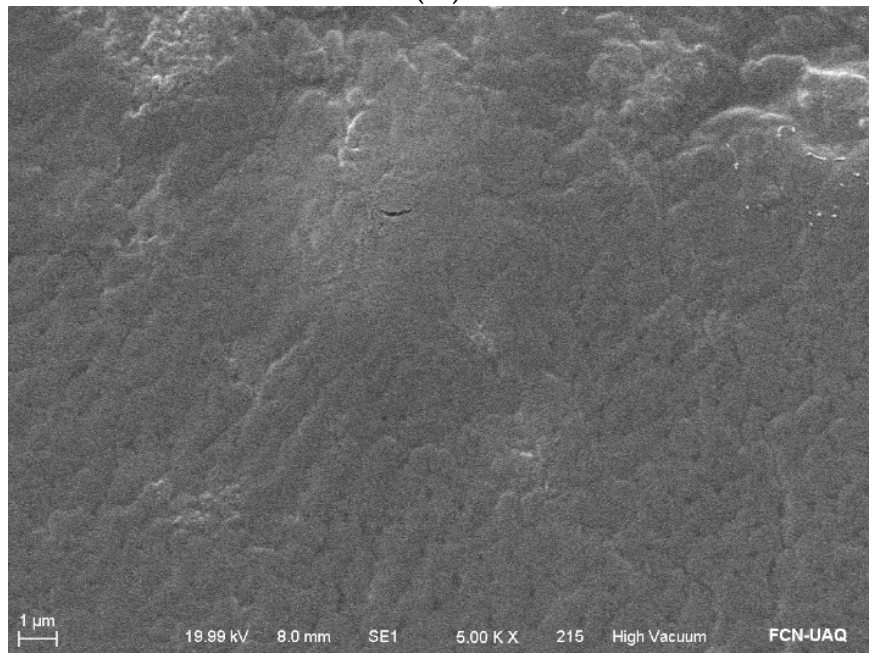

(B)

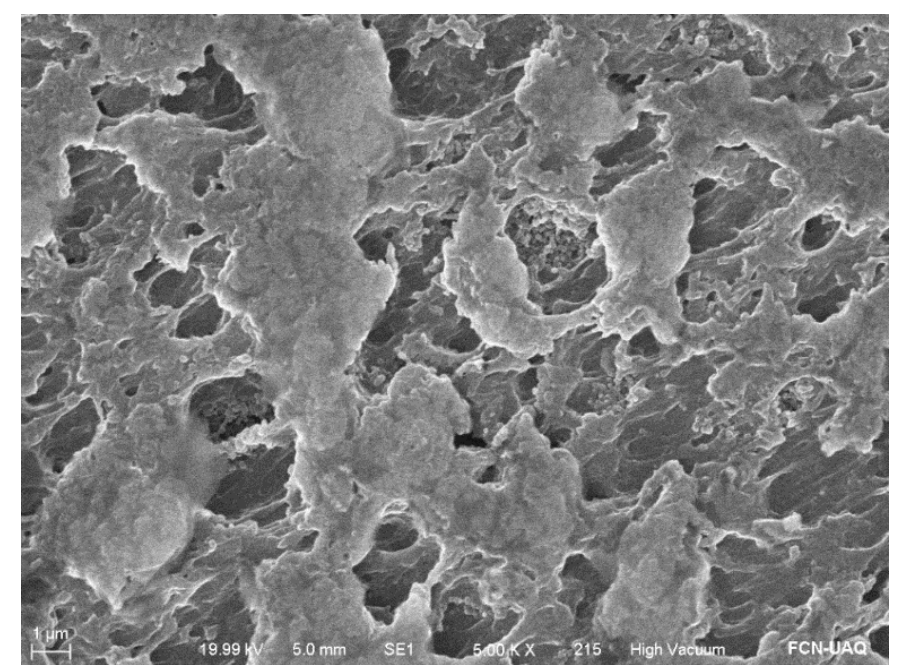

(C1)

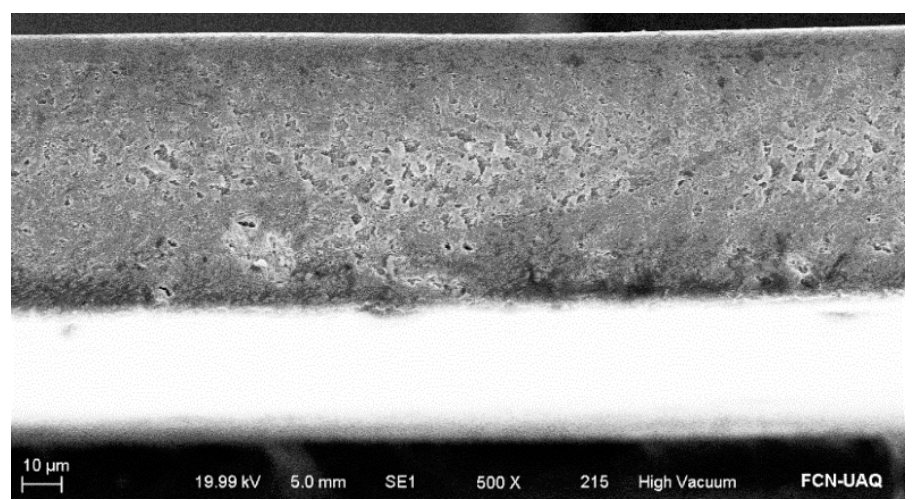

(C2)

Figure 2. SEM micrographs of films made from $50 \mathrm{~mL}$ of FFS; magnification: $5000 \times$. (A) SC:CH 8:1. (B) SC:CH 8:1 MSN-OEO. (C1) Cross section SC:CH-8:1 MSN-OEO. (C2) Cross section SC:CH-8:1-MSN-OEO (Magnification: 500×).

In conclusion, the structural differences are clearly visible due to the addition of MSN-OEO, probably due to different drying behavior, which resulted in the exposure of the MSN-OEO particles between layers of the complex SC: $\mathrm{CH}$.

\subsubsection{Thickness}

The produced edible films were transparent and flexible, and their thickness is an important factor in creating a modified atmosphere able to delay food spoilage. Films thickness varied between $57.5 \pm 5.1$ and $69.2 \pm 4.7 \mu \mathrm{m}$ (Figure 3). Pereda et al. [34], obtained similar results for films made with ratio 8:1 (SC:CH) ratio with thickness ranging 50-90 $\mu \mathrm{m}$. Addition of MSN-OEO to the FFS produced slightly decreased films thickness, with lower value for the SC: $\mathrm{CH}$ (8:1 ratio) attributed to high protein concentration, producing increased interactions with the MSN-OEO, and avoiding particles agglomeration. However, we could not find any significant thickness difference among the different films. 


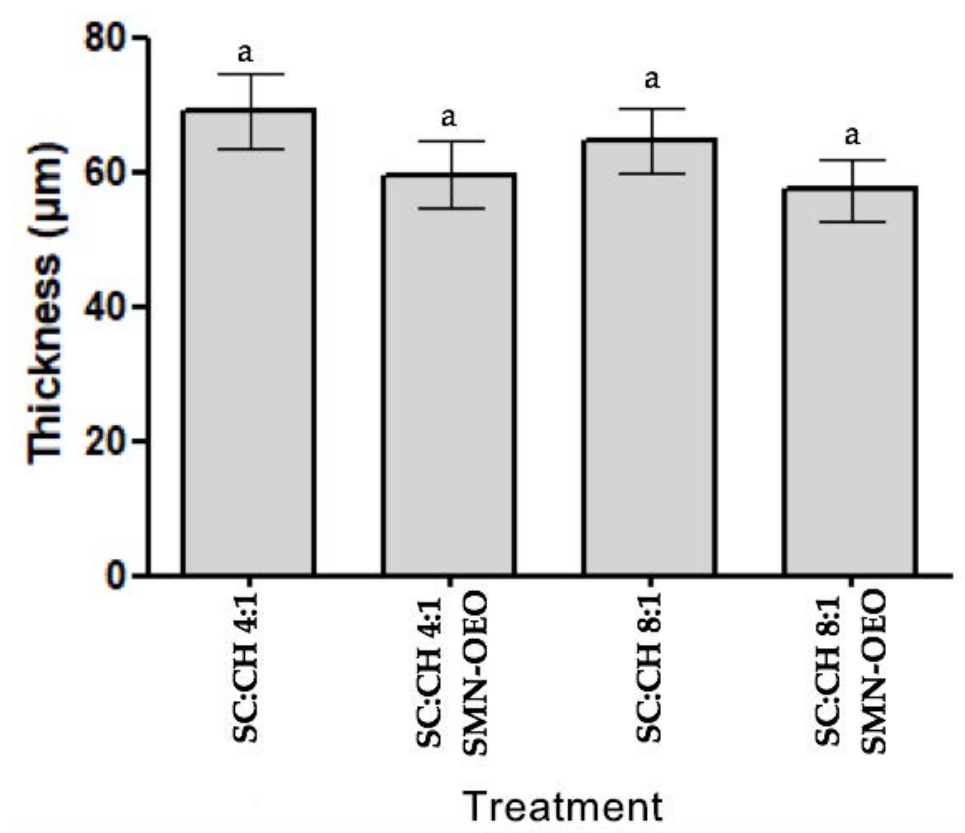

Figure 3. Thickness of SC:CH films with and without the presence of MSN-OEO.

\subsubsection{Solubility of the Films}

The solubility of the films produced in this work ranged from $34.6 \% \pm 1.3 \%$ to $36.8 \% \pm 1.2 \%$. $(w / v)$. Films containing MSN-OEO showed slightly decreased solubility, whereas films having more SC content were more water soluble. The solubility in edible films and coatings is an important parameter for fresh cheese due to syneresis or liquid leakage, causing packaging biopolymers to dissolve. Vahedikia et al. [24], reported zein protein films solubility of $40.1 \%$, which slightly decreased by addition of chitosan-cinnamon EO to $39.1 \%$. The addition of nanocomposites shows a more hydrophobic pattern, mainly due to the interaction of the $\mathrm{EO}$ components with side chain groups of the amino acids of the protein matrix.

\subsubsection{Optical Properties of the Films}

The addition of the MSN into the films did not exhibit significant difference in the $\mathrm{L}^{*}$ parameter (Table 2 ). The films presented high $\mathrm{L}^{*}$ values, whereas $\mathrm{a}^{*}$ and $\mathrm{b}^{*}$ values are close to the $\mathrm{L}^{*}$ axis, indicating low saturation (i.e., dull color), essentially gray. The SC:CH films prepared with MSN-OEO revealed a transparency of $0.82 \pm 0.0$, whereas addition of MSN-OEO to the FFS resulted in significantly improved films transparency, which may permit consumers a clearer appreciation of the food surface. Transparency may affect appearance, merchandising and applications, and greater values in edible films and coatings can confer better food visibility. The optical properties of edible packaging depend on the characteristics of the compounds and the film preparation conditions: $\mathrm{pH}$, homogenization and drying. Lin et al. [6], presented good transparency for SC films $(0.97 \pm 0.3)$, but addition of $1.5 \mathrm{mg}$ of the cross-linking agent genipin, it increased to $3.69 \pm 0.4$. The transparency values obtained in this work compared favorably to those of synthetic films, such as low-density polyethylene, directional polypropylene and polyvinyl chloride that were 3.05, 1.67 and 4.58, respectively [35]. The transparency of the edible SC:CH films significantly increased by adding the MSN-OEO. 
Table 2. Color analysis and transparency of SC:CH films with MSN-OEO.

\begin{tabular}{cccccc}
\hline SC:CH Ratio & MSN-OEO & L $^{*}$ & $\mathbf{a}^{*}$ & $\mathbf{b}^{*}$ & Transparency \\
\hline $4: 1$ & + & $91.62 \pm 0.2^{\mathrm{a}}$ & $0.33 \pm 0.0^{\mathrm{a}, \mathrm{b}}$ & $-1.16 \pm 0.2^{\mathrm{a}}$ & $0.89 \pm 0.0^{\mathrm{a}}$ \\
$4: 1$ & - & $92.00 \pm 0.1^{\mathrm{a}}$ & $0.34 \pm 0.0^{\mathrm{a}, \mathrm{b}}$ & $-1.39 \pm 0.1^{\mathrm{a}}$ & $1.14 \pm 0.1^{\mathrm{b}, \mathrm{c}}$ \\
$8: 1$ & + & $92.01 \pm 0.3^{\mathrm{a}}$ & $0.29 \pm 0.0^{\mathrm{b}}$ & $-1.18 \pm 0.4^{\mathrm{a}}$ & $0.82 \pm 0.0^{\mathrm{c}}$ \\
$8: 1$ & - & $92.19 \pm 0.1^{\mathrm{a}}$ & $0.39 \pm 0.0^{\mathrm{a}}$ & $-1.79 \pm 0.0^{\mathrm{a}}$ & $1.03 \pm 0.0^{\mathrm{a}, \mathrm{b}}$ \\
\hline
\end{tabular}

SC: sodium caseinate, $\mathrm{CH}$ : chitosan, MSN-OEO: mesoporous silica nanoparticles filled with oregano essential oil Results are reported as the mean \pm standard deviation $(n=3)$. Equal letters indicate that there is no significant difference $(p<0.05)$.

\subsection{Surface Roughness of the Films}

From the three-dimensional image of the films surfaces (Figure 4), those based on SC:CH (4:1) show significantly larger surface roughness than those using the 8:1 ratio (Table 3), probably associated to the protein supper-aggregation due to higher protein content. However, addition of MSN-OEO causes an increase in surface roughness, especially for the SC:CH (8:1) film (Figure 4). This film also shows some isolated microparticles that in the presence of MSN-OEO are less visible, but with more evident peaks and valleys leading to significantly higher $\mathrm{Ra}$ and $\mathrm{Rq}$ values (Table 3); additionally, the presence of MSN-OEO produces films showing similar roughness for both SC: $\mathrm{CH}$ ratios.
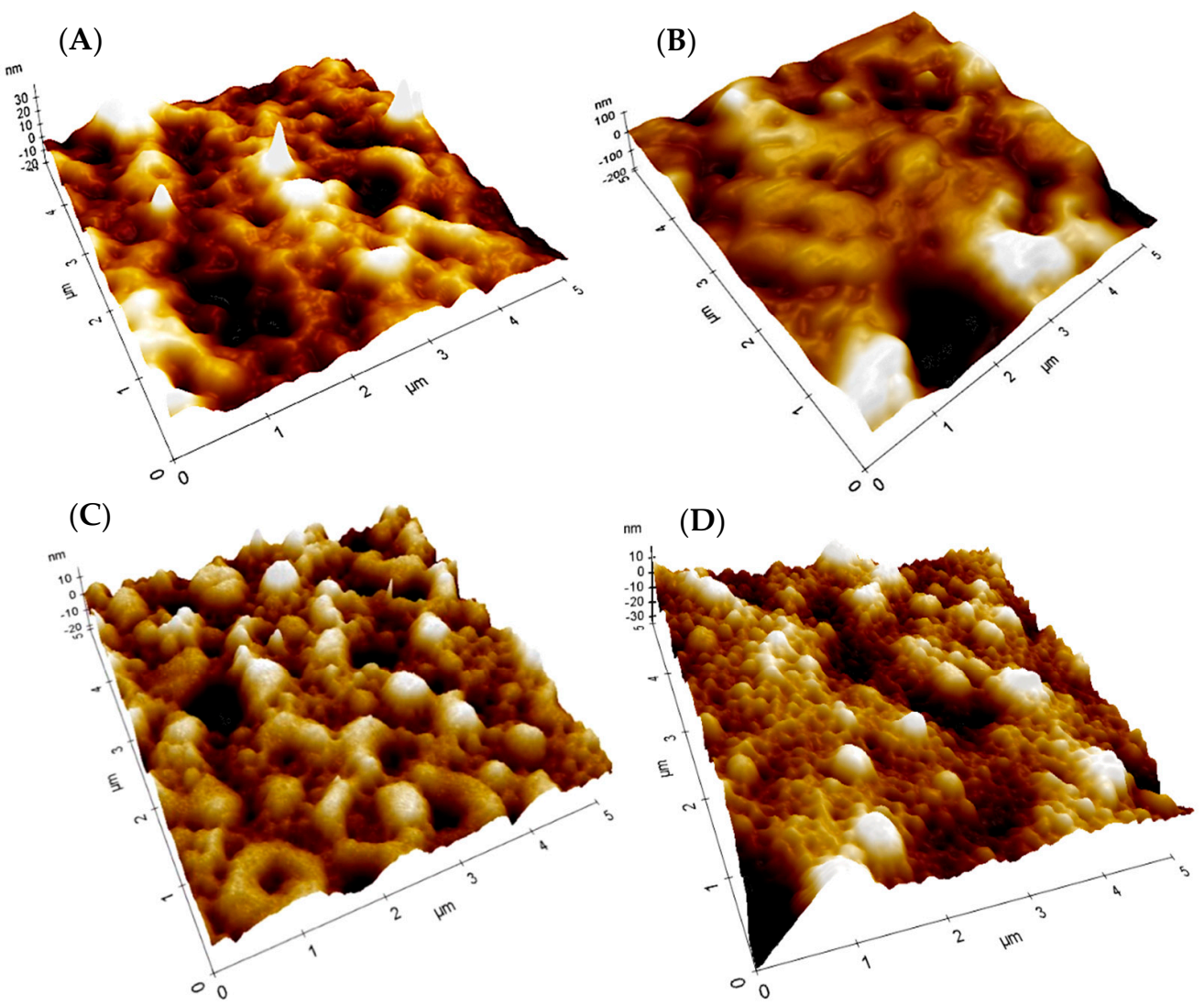

Figure 4. AFM micrographs of SC:CH films with and without MSN-OEO. (A) SC:CH 8:1 (w/w); (B) SC:CH 8:1 (w/w) MSN-OEO; (C) SC:CH 4:1 (w/w): (D) SC:CH 4:1 (w/w) MSN-OEO. 
Table 3. Roughness parameters obtained from AFM analysis of films based on SC:CH, with and without MSN-OEO.

\begin{tabular}{ccc}
\hline Treatment & $\boldsymbol{R}_{\boldsymbol{q}}(\mathbf{n m})$ & $\boldsymbol{R}_{\boldsymbol{a}}(\boldsymbol{n m})$ \\
\hline SC:CH 8:1 & $3.20 \pm 1.0^{\mathrm{a}}$ & $1.05 \pm 0.2^{\mathrm{a}}$ \\
SC:CH 8:1 MSN-OEO & $5.04 \pm 0.6^{\mathrm{b}}$ & $3.89 \pm 0.5^{\mathrm{b}}$ \\
SC:CH 4:1 & $3.76 \pm 0.9^{\mathrm{b}}$ & $2.88 \pm 0.6^{\mathrm{b}}$ \\
SC:CH 4:1 MSN-OEO & $4.50 \pm 0.3^{\mathrm{b}}$ & $3.44 \pm 0.2^{\mathrm{b}}$
\end{tabular}

Rq: square root of the deviation from an average plane of the peaks and surface valleys, Ra: mean absolute value of surface height deviations from the middle plane. Results are mean values \pm standard deviation $(n=3)$. Different letters indicate significant difference $(p<0.05)$.

In the SC-CH films micrographs, the observed agglomerations are attributed to reduction of electrostatic repulsions of the protein, due to close proximity to its isoelectric point. The agglomerations are larger in the 8:1 ratio than in the 4:1 ratio, in agreement with Anal et al. [28], who observed that increased $\mathrm{CH}$ concentration in the SC: $\mathrm{CH}$ complexes produced a slight increase in particle size, attributed to fewer aggregations. The SC:CH 4:1 MSN-OEO film surface presented better dispersion of the MSN, due to decreased -OH groups. According to Lu et al. [36], as the amount of MSN:OEO increases the pores diameter decrease and become denser, thus favoring their dispersion.

\subsection{Mechanical Properties of the Films}

Mechanical properties expressed as tensile strength (TS), elongation at break (EB) and Young's modulus (YM) of the SC:CH films are shown in Table 4. The samples containing MSN-OEO presented significantly higher TS $(p>0.05)$, and slightly decreased EB values compared to those without MSN-OEO. According to Giosafatto et al. [37], the mechanical properties can be associated to a great extent with the distribution and density of biopolymer molecular interactions that determine the films network. In addition, the mechanical properties of packaging materials arise from the intramolecular and intermolecular interactions of the biopolymers, and this depends entirely on the nature of their components. Lin et al. [6], reported similar results in relation to TS and EB for SC films crosslinked with genipin.

Table 4. Mechanical properties of SC:CH films with MSN-OEO.

\begin{tabular}{ccccc}
\hline SC:CH Ratio & MSN-OEO & $\begin{array}{c}\text { Tensile Stress at } \\
\text { Break (MPa) }\end{array}$ & $\begin{array}{c}\text { Elongation at } \\
\text { Break (\%) }\end{array}$ & $\begin{array}{c}\text { Young's } \\
\text { Modulus (MPa) }\end{array}$ \\
\hline $4: 1$ & - & $7.06 \pm 0.9^{\mathrm{a}, \mathrm{b}}$ & $103.24 \pm 2.4^{\mathrm{a}}$ & $12.48 \pm 1.4^{\mathrm{a}}$ \\
$4: 1$ & + & $8.71 \pm 1.6^{\mathrm{a}}$ & $99.52 \pm 1.3^{\mathrm{a}, \mathrm{b}}$ & $15.71 \pm 1.4^{\mathrm{a}}$ \\
$8: 1$ & - & $4.59 \pm 0.6^{\mathrm{b}}$ & $97.81 \pm 0.3^{\mathrm{b}}$ & $7.60 \pm 3.0^{\mathrm{b}}$ \\
$8: 1$ & + & $9.11 \pm 1.9^{\mathrm{a}}$ & $94.12 \pm 2.2^{\mathrm{c}}$ & $13.70 \pm 2.3^{\mathrm{a}}$ \\
\hline
\end{tabular}

Results are reported as the mean \pm standard deviation $(n=3)$. Equal letters indicate that there is no significant difference $(p<0.05)$. Tensile strength (TS) significantly, increased when MSN-OEO was incorporated for both 4:1 and 8:1 SC: $\mathrm{CH}$ ratios $(p>0.05)$, but the latter increased twice the value without MSN-OEO. This could be primarily explained by the reinforcement effect of the nanoparticles on the network structure, and to a strong interaction between the biopolymers and the MSN-OEO surface through the remaining free side chain groups of SC and amino groups of $\mathrm{CH}$ that are not involved in electrostatic interactions during complexation. According to Ojagh et al. [38] this effect leads to decreased free volume and molecular mobility of the biopolymers with a consequent increase in TS and decrease in EB. This effect is observed significantly $(p>0.05)$ in the SC:CH 8:1 films values, indicating a greater number of these interactions within the biopolymers network.

Several studies have shown that the SC-CH films structure depends on their proportion and concentration. The mechanical properties of $\mathrm{SC}-\mathrm{CH}$ films are affected by the number of cross-links formed between the $\mathrm{CH}$ and $\mathrm{SC}$, and increasing the SC proportion 
stimulates the crosslinking, forming a three-dimensional network that allows a structure with greater resistance [30].

Finally, a significant increase in YM was observed for the SC:CH 8:1 when adding MSN-OEO, whereas the 4:1 SC:CH ratio showed a moderate increase only. It is well known that the increase of interactions among polymer chains decreases their mobility increasing the stiffness, leading to increased YM values. Thus, this effect is in line with previous reports on the presence of higher number of crosslinks in the SC: $\mathrm{CH}$ 8:1 ratio films, containing MSN-OEO (Table 4)

\subsection{Barrier Properties}

The samples without MSN-OEO showed larger permeability to $\mathrm{CO}_{2}$, especially significant for the SC: $\mathrm{CH}$ (4:1) film (Table 5). Upon the incorporation of MSN-OEO, the films demonstrated a positive effect because the permeability to $\mathrm{CO}_{2}$ and $\mathrm{WV}$ decreased.

Table 5. Permeability to gases of the SC:CH films with and without MSN-OEO.

\begin{tabular}{|c|c|c|c|}
\hline \multirow{2}{*}{ Material } & $\mathrm{O}_{2}$ & $\mathrm{CO}_{2}$ & WVP \\
\hline & \multicolumn{3}{|c|}{$\mathrm{cm}^{3} \cdot \mathrm{mm} /\left(\mathrm{m}^{2} \cdot 24 \mathrm{~h}\right)$} \\
\hline 4:1 SC:CH & $0.260 \pm 0.0^{\mathrm{a}, \mathrm{b}}$ & $3.659 \pm 0.3^{\mathrm{a}}$ & $0.0806 \pm 0.0^{\mathrm{a}}$ \\
\hline 4:1 SC:CH MSN-OEO & $0.218 \pm 0.0^{\mathrm{b}}$ & $0.214 \pm 0.0^{b}$ & $0.0144 \pm 0.0^{b}$ \\
\hline 8:1 SC:CH & $0.217 \pm 0.0^{b}$ & $0.514 \pm 0.0^{b}$ & $0.0735 \pm 0.0^{\mathrm{a}}$ \\
\hline 8:1 SC:CH MSN-OEO & $0.328 \pm 0.0^{\mathrm{a}}$ & $0.340 \pm 0.0^{b}$ & $0.0321 \pm 0.0^{b}$ \\
\hline Mater-BI * & $22.69 \pm 0.1$ & $8.35 \pm 0.2$ & $15.68 \pm 0.1$ \\
\hline Low-density polyethylene ${ }^{* *}$ & 7 & 1 & 0.2 \\
\hline High-density polyethylene ** & 1 & 0.03 & 0.04 \\
\hline
\end{tabular}

$\overline{\mathrm{WVP}}=\mathrm{WV}$ permeability. Results are reported as the mean \pm standard deviation $(n=3)$. Equal letters indicate that there is no significant difference $(p<0.05) .{ }^{*}$ (Di Pierro et al. [39]. ${ }^{* *}$ Low- and high-density polyethylene (Di Pierro et al. [40]).

The hydrophilic nature of proteins and polysaccharides-based films or coatings makes them sensitive to moisture transfer, affecting their WV barrier properties. However, the OEO incorporated within the films provides a hydrophobic character resulting in lower WV permeability. Fernandez-Bats et al. [21], reported a reduction in permeability to $\mathrm{O}_{2}$ and $\mathrm{CO}_{2}$ when adding NSM in films made with pea protein and pea protein with chitosan, respectively. The low $\mathrm{O}_{2}$ permeability of the films with and without MSN-OEO is remarkable, being 70 times lower than Mater BI, a commercially available film; and 20 times less than low-density polyethylene. Oxygen permeability is of vital importance since its presence in certain foods causes microbial growth and oxidation reactions that affect the taste, quality and acceptability of food. Similarly, the low WV permeability of films with and without MSN-OEO is significantly less than Mater BI and low-density polyethylene, and slightly less than that of high-density polyethylene. WV permeability is important in coatings because they help to reduce water transfer between the food and its environment, causing less deterioration of the food and extending its storage life.

\subsection{Antimicrobial Activity}

The inhibition halos exhibited by OEO, MSN-OEO, SC: $\mathrm{CH}$ and these films incorporated with MSN-OEO indicated antimicrobial activity (Table 6). The greatest effect was observed against L. innocua (Gram +), whereas S. Saintpaul (Gram -) was not inhibited by the plain SC:CH films. Carmagnini et al. [41], showed inhibition zone of $5 \mathrm{~mm}$ for $25 \%$ OEO concentration against L. monocytogenes and S. enteritidis. Iturriaga et al. [42], showed antimicrobial effect of different EOs against L. innocua, and observed higher inhibition at lower temperature $\left(4^{\circ} \mathrm{C}\right)$. The decreased antimicrobial activity of MSN-OEO was attributed to the screening effect of other compounds present in the FFS that reduces their diffusion [43]. 
Table 6. Inhibition zone of oregano essential oil (OEO) in the SC:CH films.

\begin{tabular}{ccccc}
\hline \multirow{2}{*}{ Microorganisms } & & \multicolumn{3}{c}{ Inhibition Zone Diameter (mm) } \\
& OEO & MSN-OEO & $\mathbf{8 : 1 ~ S C : C H ~}$ & $\mathbf{8 : 1 ~ S C : C H ~ M S N - O E O ~}$ \\
\cline { 2 - 5 } & $\mathbf{2 5 \%}$ & $\mathbf{8} \mathbf{~ m g}$ & $\mathbf{0 ~} \mathbf{~ m g}$ & $\mathbf{8 ~ \mathbf { ~ g ~ }}$ \\
\hline L. innocua & $24.8 \pm 2.4^{\mathrm{a}}$ & $6.0 \pm 0.2^{\mathrm{a}}$ & $0.2 \pm 0.0^{\mathrm{a}}$ & $3.5 \pm 0.5^{\mathrm{a}}$ \\
S. Saintpaul & $8.3 \pm 2.5^{\mathrm{b}}$ & $2.7 \pm 1.5^{\mathrm{b}}$ & $\mathrm{ND}$ & $2.2 \pm 1.0^{\mathrm{a}}$ \\
\hline
\end{tabular}

Results are reported as the mean \pm standard deviation $(n=3)$. Equal letters indicate that there is no significant difference $(p<0.05)$.

\subsection{Application of FFS on Panela Cheese}

\subsubsection{Moisture Content}

The FFS of SC:CH 8:1 with and without MSN-OEO was chosen to coat Panela cheese because of better physicochemical and antimicrobial properties. The effect of the different edible coatings used here on the evolution of Panela cheese moisture content, during the 15 days of refrigerated storage is shown in Figure 5. Control samples showed the highest moisture losses $(54.5 \% \pm 2 \%)$, whereas those coated with MSN-OEO $(13 \% \pm 1 \%)$ and without MSN-OEO $(22 \% \pm 1 \%)$ showed lower moisture loss after 15 days of storage.

Visual evaluation confirmed that uncoated cheeses suffered severe water loss compared to coated cheeses after 15 days of storage (results not shown). In addition, the uncoated Panela cheese showed cracks attributed to water migration to the surface, which was not observed in coated cheeses with and without MSN-OEO. Moisture content changes are expected, because of whey losses due to syneresis occurring throughout the storage of fresh cheeses.

Cheese fat causes a yellowish color appearing when the surface dries out together with a leathery crust, unpleasant for most consumers [44]. In a study by Zhong et al. [45], Mozzarella cheese moisture loss was higher in coated (about 25\%) than in uncoated cheese, but it must be considered that the initial moisture of the coated cheeses was significantly higher than that of the uncoated cheeses, essentially due to the water present in the coating itself.

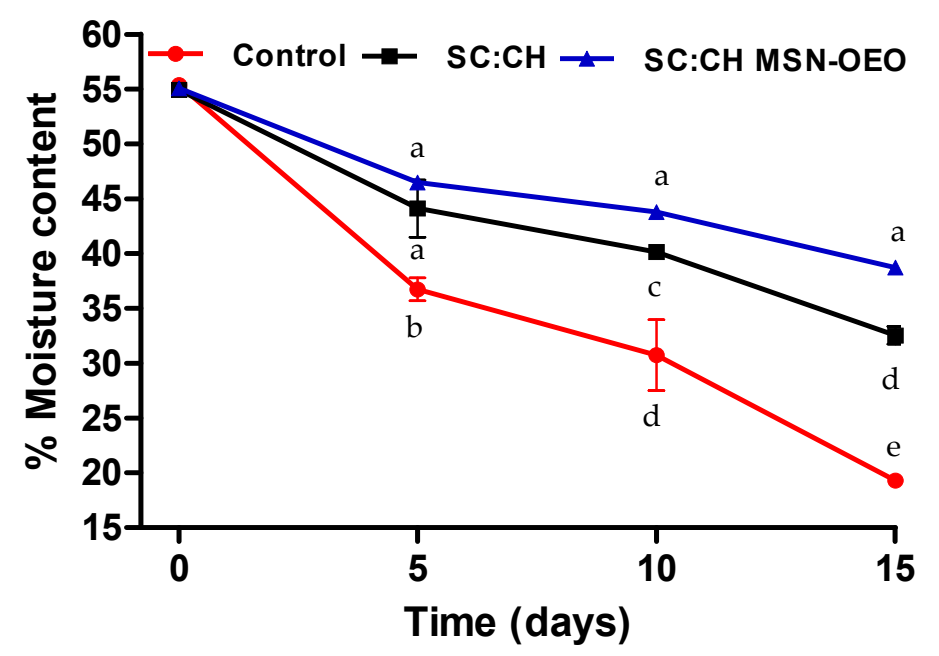

Figure 5. Moisture content of Panela cheese uncoated (control) and coated with SC:CH (8:1), and SC:CH (8:1) MSN-OEO. Different letters indicate significant differences $(p<0.05)$ for moisture content of each day.

\subsection{2. $\mathrm{pH}$ and Titratable Acidity (TA)}

Along the storage period of Panela cheese, the TA increased until day 5 , then moderately increased between days 5 and 10. Afterwards, a steep increase occurred from day 10 to the end of the storage time, achieving about $0.85 \%$ lactic acid for coated cheese with and without MSN-OEO, whereas the control cheese showed about $60 \%$ higher lactic acid 
content. Coated Panela cheese exhibited significantly $(p<0.05)$ lower TA than the uncoated cheese (Figure 6) during the whole storage period. A similar behavior was reported for Ricotta cheese covered with a film of milk protein and chitosan observing that the TA of the samples varied between $1.10 \%$ and $2.82 \%(w / w)$ [46]. The increase in TA is attributed to the production of organic acids, mainly lactic acid produced by the bacterial population that increased during storage. The coated cheeses, irrespective of the EO used, showed a moderate decrease in TA, probably due to the partial inhibition of lactic acid bacteria.

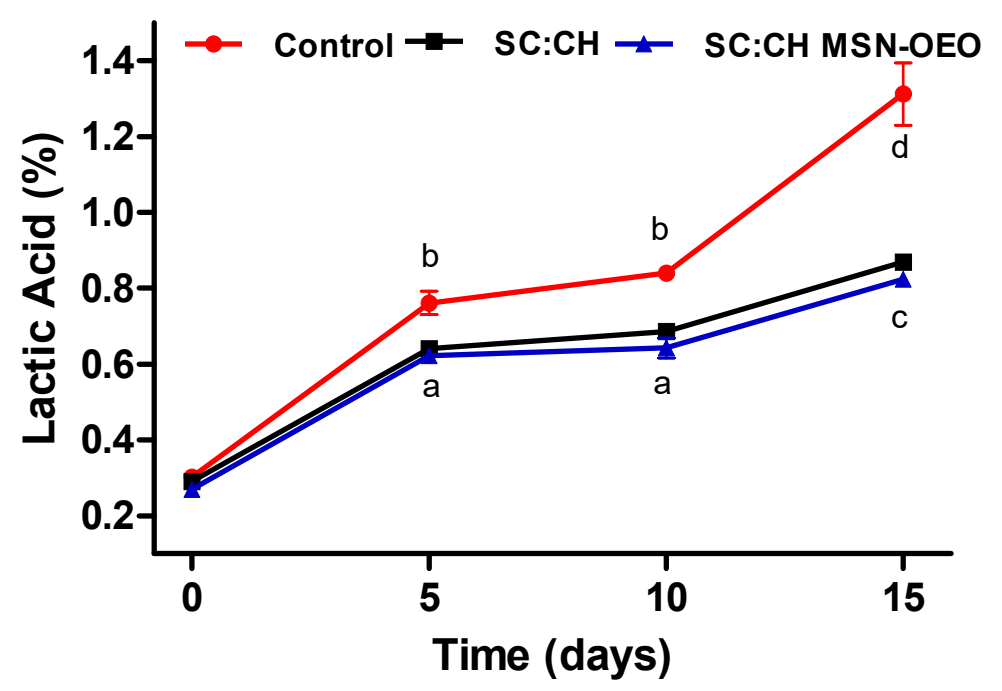

Figure 6. Changes in acidity in coated and uncoated Panela cheese, expressed as lactic acid. Different letters indicate significant differences $(p<0.05)$ for lactic acid content of each day.

The $\mathrm{pH}$ of the stored cheese showed a decreasing trend over time for coated and uncoated cheeses (Figure 7). The final $\mathrm{pH}$ of the cheeses was $5.70 \pm 0.1$ for the control cheese, $6.0 \pm 0.0$ for coated cheese, and $6.2 \pm 0.1$ for that coated with SC:CH MSN-OEO. All values recorded for each day are significantly different $(p<0.05)$.

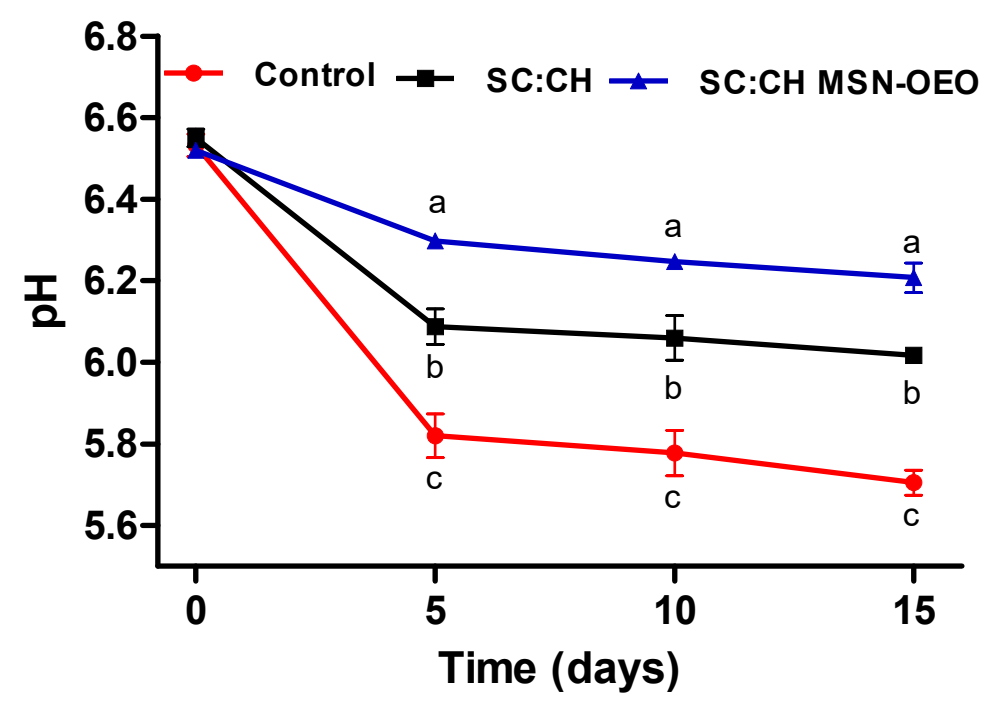

Figure 7. Values of $\mathrm{pH}$ of the coated and uncoated Panela cheese. Different letters indicate significant differences $(p<0.05)$ for $\mathrm{pH}$ of each day.

\subsubsection{Microbiological Analysis}

The application of the SC: $\mathrm{CH}$ coating to control microbial populations was effective. The total count of mesophilic aerobic bacteria, and yeasts and molds were lower in coated 
than in uncoated cheeses on days 5 and 15 (Figure 8). The population of mesophilic aerobic bacteria and yeasts increased over time as a result of decreased $\mathrm{pH}$ and increased TA probably due to microbial growth.
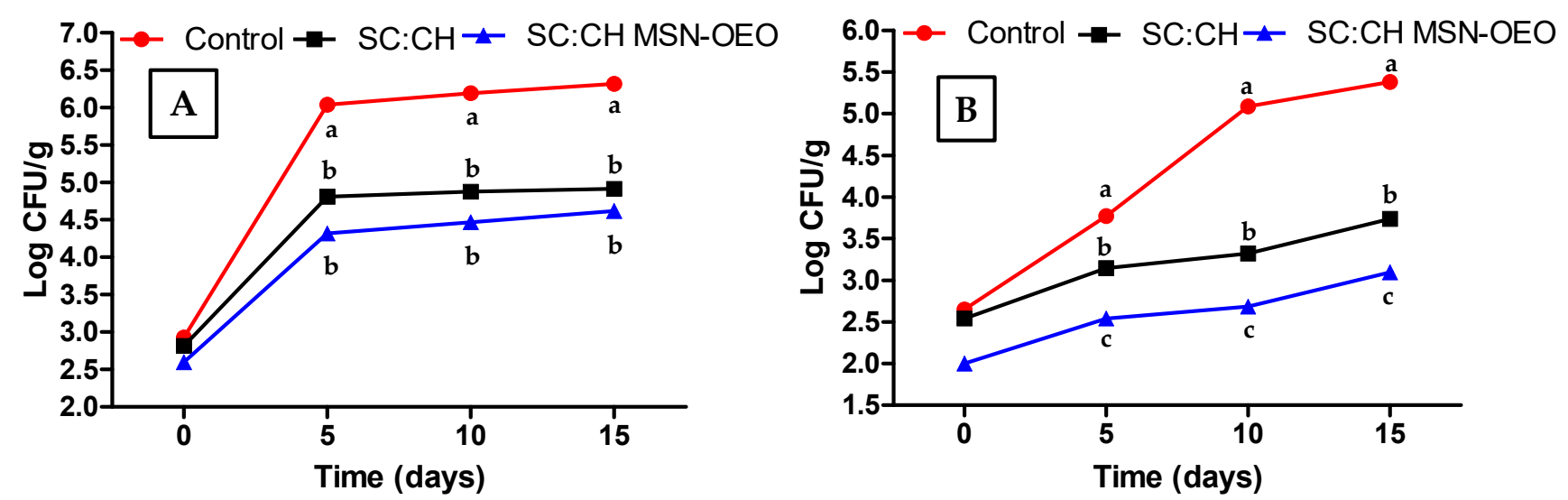

Figure 8. Antimicrobial activity of Panela cheese with and without edible coating. (A) mesophilic aerobic bacteria. (B) molds and yeasts. Different letters indicate significant differences $(p<0.05)$ for microbial population of each day.

Initially, all cheeses showed a total count of molds and yeasts below the specified Mexican standard limit (500 CFU/g), but the population of uncoated cheese showed a quick growth to reach $5 \log _{10} \mathrm{CFU} / \mathrm{g}$ after $5 \mathrm{~d}$. The coating with MSN-OEO showed the lowest population, since after 15 days it exhibited a reduction of $2 \log _{10} \mathrm{CFU} / \mathrm{g}$ compared to the control. On the other hand, the aerobic mesophilic bacterial population showed significant difference between the control and the coated cheeses over the storage time. Mei et al. [47], working with coated Mongolian cheese with a mixture of starch-chitosan, reported that after 15 days coated cheese revealed lower total count of aerobic mesophilic microorganisms and fungi compared to uncoated cheese.

The cheese coated with the SC:CH MSN-OEO showed a decrease of $1.75 \log _{10} \mathrm{CFU} / \mathrm{g}$ of mesophilic aerobic bacteria compared to the uncoated one after 15 days of storage. It must be noted that coating protects the microbial contamination from the cheese surface, whereas microbial growth is also occurring inside the cheese. It may be possible to delay microbial growth by storing the cheeses under vacuum, to avoid contact with the air from the environment.

It was decided to store the cheese samples in clamshell containers, because many fresh cheeses are stored in Mexico in this way. Artiga-Artigas et al. [48] used a coating of sodium alginate and mandarin fiber with $2 \%(w / w)$ OEO on low-fat cheese bars, placed in polyethylene trays heat sealed using a film made of polyamide and polyethylene. This procedure effectively protected the cheese from fungus and yeast after 13 days of storage.

\section{Conclusions}

SC:CH has good film-forming properties and coating capabilities, with high stability of the film forming solution. Tensile strength, elongation and barrier properties were positively influenced by the addition MSN-OEO. In addition, the thickness and reduction of water solubility of SC:CH films were improved. The films showed inhibition of Gram (+) and Gram ( - ) bacteria. The coating on Panela cheese delayed acidification and moisture loss. Microbial population over the 15 days storage period was reduced in coated Panela cheese compared to the uncoated one. Therefore, this SC:CH coating added with MSN-OEO may be successfully used to increase Panela cheese shelf life.

Author Contributions: Conceptualization, P.D.P. and C.R.-G.; methodology and validation, M.E.-G. and B.G.-A.; investigation, L.F.R.-d.-B. and A.A.-R.; resources, P.D.P. and C.R.-G.; writing-original draft preparation, L.F.R.-d.-B.; writing-review and editing, P.D.P. and C.R.-G.; visualization, B.G.-A. 
and M.E.-G.; supervision, C.R.-G. and P.D.P. All authors have read and agreed to the published version of the manuscript.

Funding: This research was funded by the Mexican Agency for International Cooperation (AMEXCID) grant No. B/ITA/17/001 and the Italian Ministries of Foreign Affairs and International Cooperation (MAECI) (Cooperazione Italia/Messico, 2018-20; PGR-2020, CUP: E68D20000670001).

Institutional Review Board Statement: Not applicable.

Informed Consent Statement: Not applicable.

Data Availability Statement: Data is contained within the article.

Conflicts of Interest: Authors declare there is no conflict of interest.

\section{References}

1. Costa, M.J.; Maciel, L.C.; Teixeira, J.A.; Vicente, A.A.; Cerqueira, M.A. Use of edible films and coatings in cheese preservation: Opportunities and challenges. Food Res. Int. 2018, 107, 84-92. [CrossRef]

2. Pavlath, A.E.; Orts, W. Edible Films and Coatings: Why, What, and How? In Edible Films and Coatings for Food Applications; Springer: New York, NY, USA, 2009; pp. 1-23. [CrossRef]

3. Lotfi, M.; Tajik, H.; Moradi, M.; Forough, M.; Divsalar, E.; Kuswandi, B. Nanostructured chitosan/ monolaurin film: Preparation, characterization and antimicrobial activity against Listeria monocytogenes on ultrafiltered white cheese. LWT-Food Sci. Technol. 2018, 92, 576-583. [CrossRef]

4. Belyamani, I.; Prochazka, F.; Assezat, G.; Debeaufort, F. Mechanical and barrier properties of extruded film made from sodium and calcium caseinates. Food Packag. Shelf Life 2014, 2, 65-72. [CrossRef]

5. Rezvani, E.; Schleining, G.; Sümen, G.; Taherian, A.R. Assessment of physical and mechanical properties of sodium caseinate and stearic acid based film-forming emulsions and edible films. J. Food Eng. 2013, 116, 598-605. [CrossRef]

6. Lin, H.C.; Wang, B.J.; Weng, Y.M. Development and characterization of sodium caseinate edible films cross-linked with genipin. LWT-Food Sci. Technol. 2020, 118, 108813. [CrossRef]

7. CANILAC. Nuevo Boletín de la Leche (ene-may2021) Final. Available online: https://www.canilec.org.mx/wp-content/uploads / 2021/06/Nuevo-Boletin-de-la-Leche-ene-may2021-PDF-final.pdf. (accessed on 13 August 2021).

8. Reyes-Díaz, R.; Gonzáles-Córdova, A.F.; Estrada-Montoya, M.; Méndez-Romero, J.I.; Mazorra-Manzano, J.Á.; Soto-Valdez, H.; Vallejo-Cordoba, B. Volatile and sensory evaluation of Mexican Fresco cheese as affected by specific wild Lactococcus lactis strains. J. Dairy Sci. 2019, 103, 242-253. [CrossRef]

9. Barukcic, I.; Scetar, M.; Marasovic, I.; Jakopovic, K.L.; Galic, K.; Bozanic, R. Evaluation of quality parameters and shelf life of fresh cheese packed under modified atmosphere. J. Food Sci. Technol. 2020, 57, 2722-2731. [CrossRef]

10. Youssef, A.M.; El-Sayed, S.M.; El-Sayed, H.S.; Salama, H.H.; Assem, F.M.; Abd El-Salam, M.H. Novel bionanocomposite materials used for packaging skimmed milk acid coagulated cheese (Karish). Int. J. Biol. Macromol. 2018, 115, 1002-1011. [CrossRef]

11. Berti, S.; Ollé Resa, C.P.; Basanta, F.; Gerschenson, L.N.; Jagus, R.J. Edible coatings on Gouda cheese as a barrier against external contamination during ripening. Food Biosci. 2019, 31, 100447. [CrossRef]

12. Burt, S. Essential oils: Their antibacterial properties and potential applications in foods-A review. Int. J. Food Microbiol. 2004, 94, 223-253. [CrossRef] [PubMed]

13. Rao, J.; Chen, B.; McClements, D.J. Improving the efficacy of essential oils as antimicrobials in foods: Mechanisms of action. Annu. Rev. Food Sci. Technol. 2019, 10, 365-387. [CrossRef]

14. Prakash, B.; Kujur, A.; Yadav, A.; Kumar, A.; Singh, P.P.; Dubey, N.K. Nanoencapsulation: An efficient technology to boost the antimicrobial potential of plant essential oils in food system. Food Control 2018, 89, 1-11. [CrossRef]

15. Sánchez-González, L.; Vargas, M.; González-Martínez, C.; Chiralt, A.; Cháfer, M. Use of essential oils in bioactive edible coatings: A Review. Food Eng. Rev. 2011, 3, 1-16. [CrossRef]

16. Asbahani, A.E.; Miladi, K.; Badri, W.; Sala, M.; Addi, E.H.A.; Casabianca, H.; Mousadik, A.E.; Hartmann, D.; Jilale, A.; Renaud, F.N.R.; et al. Essential oils: From extraction to encapsulation. Int. J. Pharm. 2015, 48, 220-243. [CrossRef]

17. Mehmood, A.; Ghafar, H.; Yaqoob, S.; Gohar, U.F.; Ahmad, B. Mesoporous silica nanoparticles: A Review. J Dev. Drugs 2017, 6, 1000174. [CrossRef]

18. Bravo, M.; Preston, G.M.; Van der Hoorn, R.A.L.; Townley, H.E.; Thompson, I.P. Species-specific antimicrobial activity of essential oils and enhancement by encapsulation in mesoporous silica nanoparticles. Ind. Crop. Prod. 2018, 122, 582-590. [CrossRef]

19. Geraci, C.; Stefani, S.; Cafiso, V.; Stracquadanio, S.; Napoli, E.; Leonardi, M.; Consoli, G.M.L.; Granata, G. Essential oils encapsulated in polymer-based nanocapsules as potential candidates for application in food preservation. Food Chem. 2018, 269, 286-292. [CrossRef]

20. Hernández-Hernández, E.; Regalado-González, C.; Vázquez-Landaverde, P.; Guerrero-Legarreta, I.; García-Almendárez, B.E. Microencapsulation, chemical characterization, and antimicrobial activity of Mexican (Lippia graveolens H.B.K.) and European (Origanum vulgare L.) oregano essential oils. Sci. World J. 2014, 2014, 641814. [CrossRef] 
21. Fernandez-Bats, I.; Di Pierro, P.; Villalonga-Santana, R.; Garcia-Almendarez, B.; Porta, R. Bioactive mesoporous silica nanocomposite films obtained from native and transglutaminase-crosslinked bitter vetch proteins. Food Hydrocolloid. 2018, 82, 106-115. [CrossRef]

22. Yilmaz, M.T.; Yilmaz, A.; Adman, P.K.; Bozkurt, F.; Dertli, E.; Basahel, A.; Al-Sasi, B.; Taylan, O.; Sagdic, O. Electrospraying method for fabrication of essential oil loaded-chitosan nanoparticle delivery systems characterized by molecular, thermal, morphological and antifungal properties. Innov. Food Sci. Technol. 2019, 52, 166-178. [CrossRef]

23. Porta, R.; Di Pierro, P.; Sabbah, M.; Regalado-Gonzales, C.; Mariniello, L.; Kadivar, M.; Arabestani, A. Blend films of pectin and bitter vetch (Vicia ervilia) proteins: Properties and effect of transglutaminase. Innov. Food Sci. Emerg. 2016, 36, 245-251. [CrossRef]

24. Vahedikia, N.; Garavand, F.; Tajeddin, B.; Cacciotti, I.; Mahdi, S. Biodegradable zein film composites reinforced with chitosan nanoparticles and cinnamon essential oil: Physical, mechanical, structural and antimicrobial attributes. Colloid. Surf. B 2019, 177, 25-32. [CrossRef] [PubMed]

25. Escamilla-García, M.; Calderón-Domínguez, G.; Chanona-Pérez, J.J.; Mendoza-Madrigal, A.G.; Di Pierro, P.; García-Almendárez, B.E.; Amaro-Reyes, A.; Regalado-González, C. Physical, structural, barrier, and antifungal characterization of chitosan-zein edible films with added essential oils. Int. J. Mol. Sci. 2017, 18, 2370. [CrossRef]

26. NOM-243-SSA1-2010. NORMA Oficial Mexicana Productos y servicios. Leche, fórmula láctea, producto lácteo combinado y derivados lácteos. Disposiciones y especificaciones sanitarias. Métodos de prueba. Retrieved 15/06/2020. Available online: http:/ / dof.gob.mx/normasOficiales/4156/salud2a/salud2a.htm (accessed on 13 August 2021).

27. Bhattacharjee, S. DLS and zeta potential-what they are and what they are not? J. Control. Release 2016, 235, 337-351. [CrossRef]

28. Anal, A.K.; Tobiassen, A.; Flanagan, J.; Singh, H. Preparation and characterization of nanoparticles formed by chitosan-caseinate interactions. Colloid Surf. B 2008, 64, 104-110. [CrossRef] [PubMed]

29. Kharlamova, A.; Nicolai, T.; Chassenieux, C. Mixtures of sodium caseinate and whey protein aggregates: Viscosity and acid- or salt-induced gelation. Int. Dairy J. 2018, 86, 110-119. [CrossRef]

30. Volpe, S.; Cavella, S.; Masi, P.; Torrieri, E. Effect of solid concentration on structure and properties of chitosan-caseinate blend films. Food Packag. Shelf Life 2017, 13, 76-84. [CrossRef]

31. Navarro, R.; Arancibia, C.; Herrera, M.L.; Matiacevich, S. Effect of type of encapsulating agent on physical properties of edible films based on alginate and thyme oil. Food Bioprod. Process. 2016, 97, 63-75. [CrossRef]

32. Mudalige, T.; Qu, H.; Van Haute, D.; Ansar, S.M.; Paredes, A.; Ingle, T. Characterization of Nanomaterials: Tools and Challenges. In Nanomaterials for Food Applications. Micro and Nano Technologies; López-Rubio, A., Fabra-Rovira, M.J., Martínez-Sanz, M., Gómez-Mascaraque, L., Eds.; Elsevier: Amsterdam, The Netherlands, 2019; pp. 313-353.

33. Fabra, M.J.; Jiménez, A.; Atarés, L.; Talens, P.; Chiralt, A. Effect of fatty acids and beeswax addition on properties of sodium caseinate dispersions and films. Biomacromolecules 2009, 10, 1500-1507. [CrossRef]

34. Pereda, M.; Aranguren, M.; Marcovich, N. Characterization of chitosan/caseinate films. J. Appl. Polymer Sci. 2007, 107, 1080-1090. [CrossRef]

35. Shiku, Y.; Hamaguchi, P.Y.; Tanaka, M. Effect of $\mathrm{pH}$ on the preparation of edible films based on fish myofibrillar proteins. Fisheries Sci. 2003, 69, 1026-1032. [CrossRef]

36. Lu, W.; Cui, R.; Zhu, B.; Qin, Y.; Cheng, G.; Li, L.; Yuan, M. Influence of clove essential oil immobilized in mesoporous silica nanoparticles on the functional properties of poly(lactic acid) biocomposite food packaging film. J. Mater. Res. Technol. 2021, 11, 1152-1161. [CrossRef]

37. Giosafatto, C.; Sabbah, M.; Al-Asmar, A.; Esposito, M.; Sanchez, A.; Villalonga Santana, R.; Cammarota, M.; Mariniello, L.; Di Pierro, P.; Porta, R. Effect of mesoporous silica nanoparticles on glycerol-plasticized anionic and cationic polysaccharide edible films. Coatings 2019, 9, 172. [CrossRef]

38. Ojagh, S.M.; Rezaei, M.; Razavi, S.H.; Hosseini, S.M.H. Development and evaluation of a novel biodegradable film made from chitosan and cinnamon essential oil with low affinity toward water. Food Chem. 2010, 122, 161-166. [CrossRef]

39. Di Pierro, P.; Villalonga, R.; Mariniello, L.; Massi, P.; Porta, R. Chitosan-Whey protein edible films produced in the absence or presence of transglutaminase: Analysis of their mechanical and barrier properties. Biomacromolecules 2006, 7, 744-749. [CrossRef] [PubMed]

40. Di Pierro, P.; Mariniello, L.; Giosafato, C.V.L.; Massi, E.; Porta, R. Solubility and permeability properties of edible pectin-soy flour films obtained in the absence or presence of transglutaminase. Food Biotechnol. 2005, 19, 37-49. [CrossRef]

41. Carmagnini, L.; Calesini, F.; Pesavento, G.; Di Martino, M.C.; Bilia, A.R.; Bernabei, M.; Calonico, C.; Mencarelli, L.; Lo Nostro, A.; Addona, R. Antibacterial activity of oregano, rosmarinus and Thymus essential oils against Staphylococcus aureus and Listeria monocytogenes in beef meat balls. Food Control. 2015, 54, 188-199. [CrossRef]

42. Iturriaga, L.; Olabarrieta, I.; de Marañón, I.M. Antimicrobial assays of natural extracts and their inhibitory effect against Listeria innocua and fish spoilage bacteria, after incorporation into biopolymer edible films. Int. J. Food Microbiol. 2012, 158, 58-64. [CrossRef] [PubMed]

43. Arredondo-Ochoa, T.; García-Almendárez, B.E.; Reyes, A.A.; Pastrana, D.M.R.; López, G.F.G.; Belloso, O.M.; Regalado-González, C. Design and characterization of corn starch edible films including beeswax and natural antimicrobials. Food Bioproc. Technol. 2017, 10, 103-114. [CrossRef]

44. De Gante, A.V.; Moreno, A.S. Los Quesos Mexicanos Tradicionales; Juan Pablos Editor: Mexico City, Mexico, 2016; Volume 14, pp. 323-326. 
45. Zhong, Y.; Cavender, G.; Zhao, Y. Investigation of different coating application methods on the performance of edible coatings on Mozzarella cheese. LWT-Food Sci. Technol. 2014, 56, 1-8. [CrossRef]

46. Di Pierro, P.; Sorrentino, A.; Mariniello, L.; Giosafatto, C.V.L.; Porta, R. Chitosan/whey protein film as active coating to extend Ricotta cheese shelf-life. LWT-Food Sci. Technol. 2010, 44, 2324-2327. [CrossRef]

47. Mei, J.; Yuan, Y.; Wu, Y.; Li, Y. Characterization of edible starch-chitosan film and its application in the storage of Mongolian cheese. Int. J. Biol. Macromol. 2013, 57, 17-21. [CrossRef]

48. Artiga-Artigas, M.; Acevedo-Fani, A.; Martín-Belloso, O. Improving the shelf life of low-fat cut cheese using nanoemulsion-based edible coatings containing oregano essential oil and mandarin fiber. Food Control 2017, 76, 1-12. [CrossRef] 